\title{
EMBRYOGENIC POTENTIAL OF CALLUS \\ DERIVED FROM AN ADULT GIANT BAMBOO \\ (Dendrocalamus giganteus Wall. ex Munro)
}

\author{
'WAVR Wanniarachchi, 'SMSD Ramanayake and 'DMSHK Ranasinghe \\ ${ }^{1}$ Institute of Fundamental Studies, Kandy \\ ${ }^{2}$ Department of Forestry and Environmental Science, University of \\ Sri Jayewardenepura, Nugegoda
}

Dendrocalamus giganteus Wall.ex Munro (giant bamboo), the largest of the bamboos in Sri Lanka, is recommended for expanded cultivation. Natural means of propagation by vegetative or sexual methods is limited in this species. In the absence of a true breeding system, novel biotechnological methods offer a para sexual alternative for genetic improvement. This would require de novo plant regeneration via callus, cell suspensions or protoplasts. With this objective in view, callus was induced from axillary shoots, spikelets and roots that formed in vitro in a continuously proliferating system of axillary shoots derived from a 70 year old field clump of $D$. giganteus. The callus proliferated in MS medium containing 4\% sucrose, 2,4-D (7.5 mgl- $\left.{ }^{-1}\right)$ and NAA $\left(3 \mathrm{mgl}^{-1}\right)$ to form nodular callus that showed a potential for plantlet regeneration. The friable callus readily formed cell suspensions in the presence of 2,4-D $\left(7.5 \mathrm{mgl}^{-1}\right)$ along or with NAA $\left(3 \mathrm{mgl}^{-1}\right)$. These cells showed organized development to form structures that resembled pro-embryos. Organogenesis/embryogenesis is novel from long established adults although it is more common in juveniles.

This report signifies the potential of a 70-year-old adult bamboo for plantlet regeneration. 